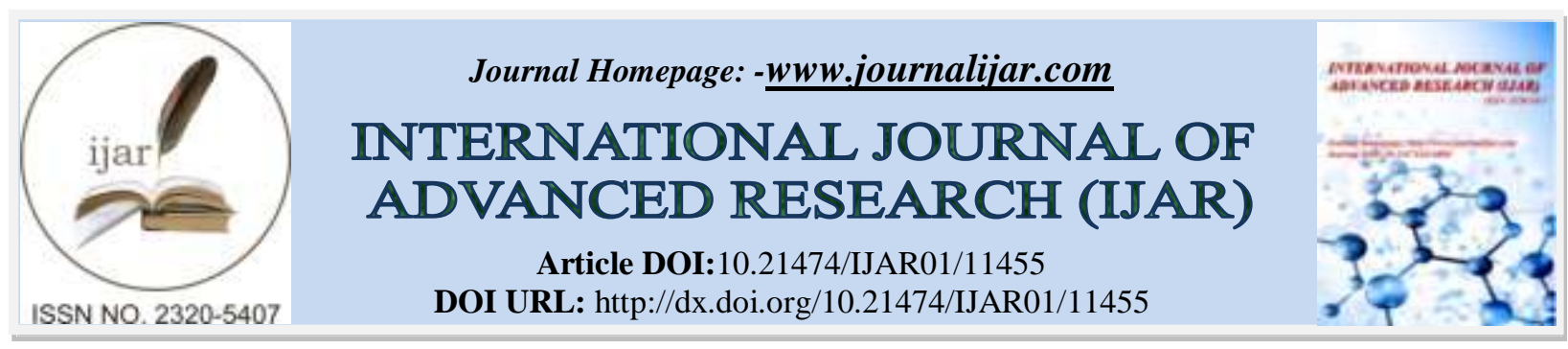

RESEARCH ARTICLE

\title{
CHANAKYA AND FUNCTIONAL MANAGEMENT IN TIMES OF CHANGE
}

Vinod Kumar K

Vocational Teacher,VHSE Department, Kerala, India.

\section{Manuscript Info Abstract}

\section{Manuscript History}

Received: 31 May 2020

Final Accepted: 30 June 2020

Published: July 2020

Key words:-

Arthasasthra, Chanakya, Management,

Accounting, Financial Management.
At the present era of Liberalised, Privatised and Globalised (LPG) dynamic business environment and competition, the success of an organisation depends upon the effective strategies framed by such organisation. Management is a continuous process and it involves numerous functions and the management focuses more on developing strategies and policies for the best possible performance of the business. While developing the strategies and policies, the management is facing many problems and issues that make difficult the effective management of the organisation. In this context of contemporary relevance of management, the various functions of management like finance, human resource management etc. is originated and practiced from ancient dynasty of Chandragupta Maurya. During this period, the Finance Minister of Chandragupta Maurya, Chanakya practiced many strategies and practices focusing on Financial Management, Human Resource Management, Strategic Management which are base of the modern scientific principles and practices in these relevant areas of management of an organisation. He wrote a book, Arthasasthra, which denotes many references regarding the principles of management of an organisation, especially the Financial Management and Accounting.

Copy Right, IJAR, 2020,. All rights reserved.

\section{Introduction:-}

About Chanakya:

During the Mayura era, Chandragupta Maurya was the emperor of Magadha. At that time, Chanakya was the political guru of emperor Chandragupta. Because of the strategic skill and political wisdom he possessed, that efficient political thinker was christened Chanakya. The childhood name of Chanakya was Vishnugupta. Due to his extremely sharp wit, he came to be known as Chanakya. Because he was an astute, wily political manipulator, he came to be known as Kautilya. Indian history is unable to give the correct detail about his birthplace. His education was completed in the Takshsila University. Chandragupta and Chanakya were contemporaries. It was the time of $325 \mathrm{BC}$, Chanakya led a very simple life. He used to live outside the main city, in a small hut. Kautilya had written Artha Shastra, Laghu Chanakya, Vriddha Chanakya, Chanakya Neeti etc. to educate the politicians in the art and craft of politics.

\section{Accounting and Financial Management in Arthasastra:}

In the classic work Arthashastra, Kautilya gave detailed instructions regarding accounting and auditing of the state finances. According to him "all undertakings depends on finance. Hence foremost attention shall be paid to the treasury". 
Kautilya's contributions to accounting may be classified under four headings: (i) the development of principles of accounting, (ii) the specification of the scope and methodology accounting, (iii) the codification of financial rules and regulations and the creation of an organizational structure to reduce the potential for conflicts of interest, and (iv) the role of ethics in the restraint of fraudulent accounting (often spawned by excessive greed), in the maintenance of law and order, the efficient allocation of resources, and the pursuit of happiness.

Mattessich [1998] sheds light on Kautilya's contributions under the first heading. He identifies elements of modern principles of accounting in Kautilya's Arthashastra and shows that it contains more accounting theory than Luca Pacioli's. Kautilya considered explanation and prediction as the objectives of analytical inquiries related to accounting. it is argued that he did not recommend separating accounting from economics. Kautilya understood the importance of the accurate measurement of economic performance to economic growth. He linked decisions on production and trade patterns to profitability and implicitly considered innovation in accounting methods as a general-purpose technology, which improved the efficiency of the whole economy. Kautilya's ideas on the importance of the financial health of the Treasury to achieve the various objectives of the state.

The content of Kautilya's work indicates that the prerequisites for the establishment of the discipline of accounting already existed in India during 4th century B.C.E.. Kautilya used fractions, percentages, summation and subtraction operations, and even permutations and combinations quite extensively, displaying a deep knowledge of arithmetic. He developed not only bookkeeping rules but also the procedures for preparing periodic income statements and budgets and performing independent audits

Kautilya added, "In the absence of fruitful economic activity, both current prosperity and future growth are in danger of destruction. A king can achieve the desired objectives and abundance of riches by undertaking productive economic activity " He advanced the hypothesis that the pursuit of productive activities was the key to stabilization of the current income and its rapid growth in the future

Incentives to Encourage Creation of Wealth in the Private Sector: Kautilya explored all possible means of creating wealth. He suggested many policies to encourage capital formation in the private sector. For example, he recommended (i) Tax Holidays: "Any one who brings new land under cultivation shall be granted exemption from payment of agricultural taxes for a period of two years. For building or improving irrigation facilities exemption from water rates shall be granted" (ii) Full Protection of Private Property Rights: Kautilya wrote "The wealth of the state shall be one acquired lawfully either by inheritance or by the king's efforts." He added, "Water works such as reservoirs, embankments and tanks can be privately owned and the owner shall be free to sell or mortgage them." (iii) Concessionary Loans: He recommended, the cultivators shall be granted grains, cattle and money which they can repay at their convenience." (iv) Duty Free Imports: Kautilya suggested "Any items that, at his discretion, the Chief Controller of Customs, may consider to be highly beneficial to the country (such as rare seeds) are to be exempt from import duties.

According to Kautilya "increasing the wealth of the State: ensuring the prosperity of state activities; continuing well tried policies; eliminating theft; keeping strict control over government employees, increasing agricultural production; promoting trade; avoiding troubles and calamities; reducing exemptions and remissions and increasing cash income. Obstruction, misuse of government property and false accounting by government servants lead to a reduction of wealth.

Kautilya emphasized heavily the financial health of the state and understood that a sound treasury was a prerequisite to accomplishing other goals. He stated, "All state activities depend first on the Treasury. Therefore, a King shall devote his best attention to it. A King with a depleted Treasury eats into the very vitality of the citizens and the country." In fact, according to Kautilya, a King should begin his day by receiving "reports on defense, revenue and expenditure. According to Kautilya, therefore, a king must carefully manage the financial affairs of the state.

Kautilya in his Sutras advances these hypotheses: "Fortune follows human effort. Prosperity depends on the intellect. Intellect depends on education." Kautilya was aware that an efficient allocation of resources depended on appropriate measurements of profits, which were critical to enhancing economic growth. 


\section{Findings:}

The above discussions are showing that Kautilya gave importance for all functions of book keeping and accounting, including recording transactions, measurement of Income of the economic activity both for the public and private sector. He gave utmost importance for the modern financial management objective of wealth maximisation, and all other functions of financial management includes Investment decisions, financing decisions ( lending of loans, raising funds for economic activity), fiscal and risk-return decisions during those days itself. He gave importance for the co-existence of public and private sector enterprises. He advised the King to implement the tax holidays, collection of taxes without any deviation, providing loans and advances to the farmers and other people for creating wealth. All these evidences showing that all the modern accounting and financial management techniques, modern government functions including the fiscal, banking, incentives for industry and thereby increasing the economic growth of both the Government and private sector was evolved and practiced during the ancient India especially during the period of Kautilya as a Minister of Chandragupta Maurya. In short all these discussions are evident that there was systematic and scientific approach towards the economy, Accounting, treasury management (Financial Management), co-existence of Public and Private sector, well developed fiscal policy and tax holidays, providing loans and advances to the needy people and all measures for the economic growth and thereby wealth maximisation was practiced during the period of Arthasastra.

\section{Personnel Management in Arthasastra: \\ Staffing:}

For the efficient performance of other functions of management, staffing is its key. Since, if an organization does not have the competent personnel, then it cannot perform the functions of management like planning, organizing and control functions properly.

The first and foremost function of staffing is to obtain qualified personnel for different jobs position in the organization.

In staffing, the right person is recruited for the right jobs, therefore it leads to maximum productivity and higher performance.

It helps in promoting the optimum utilization of human resource through various aspects.

Job satisfaction and morale of the workers increases through the recruitment of the right person.

Staffing helps to ensure better utilization of human resources.

It ensures the continuity and growth of the organization, through development managers.

\section{Human Resource Management According to Chanakya: Identifying a Person:}

The success or failure of a person/organisation depends heavily up on his capability of identifying the right person. If an organisation is able to find the right person, one's way to success becomes very smooth.

Chanakya has given many formulas to recognize a person.

A person should be tested on the grounds of wisdom and guess. If a person has neither any knowledge about a given piece of work nor done any similar piece of work in the past, it becomes too difficult for that person to be successful in that particular work realm. So, while choosing a person for any kind of work, due consideration should be given to his wisdom and experience. This principle is known as the 'Division of Work' which are proposed by Henri Fayol in his famous 14 Principles of management.

Regarding testing of a person : Those people who remain with you even during your bad times, are your true wellwishers. Hence, you should invest your faith only in such people. The ones, who did not give you support during such (tough) times, should never be trusted in the future.

Management Guru Chanakya has clearly written in Chanakya Neethi about the process of recognizing and testing a person who is to be trusted regarding a piece of work. Kautilya says that gold is tested by grinding, cutting, heating 
and beating. Similarly, man is tested on the basis of his sacrifice, perseverance, virtues and deeds. A good, noble man is one who has good virtues. His deeds are visible good, output is also very good and up to the mark. Hence, such types of person can be trusted.

He said that we should not give any importance to the tasks done by the foolish people. This should be a typical basis for recognizing a person. There is always a possibility that a person may perform a piece of work inadvertently. Despite this, he may not realize how he was able to do that piece of work. So, a person should not be selected only on the basis of one particular piece of work; rather, it should be a basis for the continuation of his work.

According to him, a person, who does not follow the rules of society, should never be trusted because he can go to any extent. The right person is the one who respects the rules of society.

If an enemy does something good for you, beware of him. He says that there must be a secret in this action of your enemy. Some point of time, your enemy may have a genuine change of heart. Such person should initially be given a piece of work of less importance. If he performs it honestly, he should be allotted other assignments. Also keep special vigil at every step that is involved. If he is up to something fishy, he would not succeed in spoiling your apple-cart.

Trusting those people is risky who are not being tested in a proper manner. Having faith in a person without testing him means inviting trouble.

A foolish person harms even his own well wishers. If you judge a person and consequently, find him to be foolish, never trust him. Trusting him would only earn disrespect and harm for you. If a genuine person is allotted a job, he will be successful in completing the job and you will be benefited too. You should not align foolish people with you because they have a negative approach. Howsoever good you may do for them, they would always adopt the evil path. That is why a person, who does something good for a foolish people, is ultimately harmed by those very people. That is why Chanakya repeatedly suggests that we should remain away from such foolish people.

Chanakya suggests to avoid wicked people while recognizing the right persons. Such people are least bothered about success or failure; and they fail others too. As they do not bother about criticism, they remain unharmed but the genuine person accompanying them has to bear the damage caused by them.

Wicked people have the inherent tendency to tease good people. These people don't hesitate to deceive even their well-wishers. Acharya suggests that we remain extra careful with such people.

Management Guru Chanakya has made it quite clear wicked people never learn. We must not preach the wicked. Acharya says that a wicked man always remain wicked. All efforts to convince him go in vain. You give him knowledge and he would ill-treat you. It is just like giving mil to a snake; he shall bite you even after drinking milk. So, do not waste your time and labour to make such people understand. Instead look for a capable person, even if you have spend more time to look for him.

\section{Leadership:}

Leadership is a process by which an executive can direct, guide and influence the behavior and work of others towards accomplishment of specific goals in a given situation. Leadership is the ability of a manager to induce the subordinates to work with confidence and zeal.

Leadership is the potential to influence behaviour of others. It is also defined as the capacity to influence a group towards the realization of a goal. Leaders are required to develop future visions, and to motivate the organizational members to want to achieve the visions.

According to Keith Davis, "Leadership is the ability to persuade others to seek defined objectives enthusiastically. It is the human factor which binds a group together and motivates it towards goals." 
The capability to lead is a compulsory virtue required to excel in any field. One, who possesses this capability, is never short of success; and people always follow him. Acharya has given many mantras that should be included in our lives to develop this capability. This will make your way to success quite easy.

A person should be allotted only that piece of work in which he specializes. This is important from the viewpoint of leadership quality. He should give the task as per the capability of the persons he is handling. This gives you two benefits, firstly, the task at hand is accomplished properly and you are appreciated. Secondly, the person, who performs the work, also matures. His self confidence increases and under normal circumstances, he gives the credit to his leader.

A sweet natured person is insulted by even those who are dependent up on him. Acharya Chanakya clearly says that being sweet natured is not a bad concept. But while managing politics, government sector firms or organizations this trait has an adverse effect.

If your subordinate commits a mistake, you must punish him but the level of the punishment should be on the basis of the gravity of his mistake. Harsh punishment should not be given for a trivial mistake. A good leader should always keep this precept in his mind.

All leaders must have the capability inside them to identify the right type of people. A good leader would try to get positive vibes or messages even from negative, wily things. If the thinking is negative, even good things, would appear to be ineffective.

The right leader has a fine identification point, he is competent for making incapable people fully capable.

Leaders must not trust wily, foxy persons even by mistake. If we trust a wily person and allocate a task to him, God knows, when he may create chaos. According to Chanakya "a wily, dirty person and a snake both are dangerous". That means a trecherous, foxy man is more dangerous than even a snake. Chanakya believes that the snake bites only once but a wily man bites at each and every step.

Leaders must also understand that the capacity and nature of every person are different. It would not be appropriate to expect the same behaviour, response or output from all of them. Hence, the leaders must allocate the tasks according to the nature of the employee.

The good leader should be capable of finding the right people and only then he would be able to complete his work and reap positive results. One of the basic quality of a leader is that he should take the responsibility of failure just as he takes the credit of success.

For a successful leader, it is also important to supervise the task allotted by him to others. In case there is a problem, he should lead the team from the front. Such behaviour incorporates the feeling of respect for the leader in the heart of the person who was given a piece of work to execute.

\section{Strategic Skills in Management:}

Management Guru Chanakya has given excellent guidelines about strategic skills. Whoever has worked out an effective strategy and implemented the same in a proper manner, has become successful. Chanakya has given the methods for developing strategic skills which are required in every field -political, business or personal life.

According to Chanakya " powerful should attack the weak. He tells us that work should be taken up by us according to our capabilities. According to him fighting against the powerful is like battling on foot against a regiment of elephants. Hence, right strategy would be to gain strength to challenge the threat.

Chanakya says that when two unbaked earthen vessels collided with each other, they are destroyed. This is one of the important mantra of Chanakya, according to him if, two immature or weak organisations are compete each other, that will be harm to both the organisation and it is better to maintain cordial relations each other. This strategy is widely applicable in the present era of competition and results in various business combinations. According to him we should keep on reviewing the efforts of your rivals and waiting for the right opportunity to against your rival and for this the thoroughly informed decisions and strategies are vital and it is appropriate to formulate or make changes 
in our plans and strategies only after knowing the complete knowledge of the changes in the plans and strategies of the rivals. According to Chanakya we must never show our own weakness to anyone.

All the above discussions and preaches of Chanakya are relevant in the contemporary strategic management scenario. Now a days formulation and implementation of the appropriate and adequate strategies and acquiring the strategic skills are very vital for the efficient operation of an enterprise. All the strategic skills like leadership, communication, tactics and motivation are very essential for the efficient running of an enterprise.

Chanakya gave detailed account of recongnising the appropriate time to complete the work successfully. According to him, everybody knows that there is an appropriate time to do a particular piece of work. The success of any person/organisation depends heavily upon efficiency. The more one is efficient, the more one is successful. According to him, we must start any piece of work after determination, unstable mind cannot complete any piece of work. He specifies the importance of utilising the available resources in an appropriate and apt manner. He says that contempt of available resources is violation of work. He highlighted that one should not hesitate in learning from any person. Besides, he must also note that every person has some specialisation or the other.

From the above discussions, we can conclude that the modern principles of management like Division of Labour (Specialisation), Optimum and efficient utilisation of resources, performing the right task at the right time, unity of direction and control, team work, discipline, participative decision making after consulting the lower level employees, communication, supervision and similar contemporary principles and techniques are proposed by Chanakya and practiced during his regime and that will be treated as the base of the systematic and scientific management.

Chanakya, in his book, Arthasasthra gave detailed account of other relevant areas of management consisting of recognition of appropriate time, importance of character, efficiency, recognising circumstances, importance of knowledge, importance of wealth, friendship, patience, company, hard work, getting rid of laziness, giving up addiction, pleasant talk, confidentiality, know yourself, taking tough decision etc. which are applicable in the management of business enterprises and later pave way to many theories and principles in the area of management.

\section{References:-}

1. Shekhar Himanshu (2010), Management Guru Chanakya, 1st Edition, Diamond Books (P) Ltd. New Delhi.

2. Subramanian, V. K. (1980), Maxims of Chanakya (New Delhi: Shakti Malik, Abhinav Publications), 2000 reprint.

3. Kangle, R. P. (1965), The Kautilya Arthasastra, Part III (Delhi: Motilal Banarsidass), 2000 reprint.

4. Sihag S Balbir, Kautilya on the Scope and Methodology of Accounting Organisatinal Design and the role of Ethics in Ancient India, Accounting Historians Journal, Vol. 31, No.2, December, 2004 retrieved from https://www.sanjeev.sabhlokcity.com/Misc/sihag-kautilya-accounting.pdf

5. Mattessich, R. (1998), "Review and Extension of Bhattacharya's Modern Accounting Concepts in Kautilya's Arthasastra," Accounting, Business \& Financial History, Vol. 8, No. 2: 191-209.

6. Mattessich, R. (2000), The Beginnings of Accounting and Accounting HistoryAccounting Practice in the Middle East (8000 B. C. to 2000 B. C.) and Accounting Thought in India (300 B. C. and the Middle Ages) (New York: Garland Publishing). 